\title{
The Correlation Between Work Environment and Work Motivation with Job Satisfaction
}

\author{
Mohamad Muspawi \\ Elementary School Teacher Education \\ Jambi University, Indonesia \\ muspawi01@gmail
}

\author{
Ruita Mudlikawati \\ Department of Educational Administration \\ Jambi University, Indonesia \\ ita_14@gmail.com
}

\begin{abstract}
This research aims at knowing the relation of work environment and work motivation with job satisfaction in Jambi Provincial Library and Archives Office. The researcher for this research used quantitative method in which the collected data is represented in variables $\mathrm{X} 1, \mathrm{X} 2$, and $\mathrm{Y}$ using questionnaire. Data analysis shows that work environment is correlated with job satisfaction based on the coefficient for the $\mathrm{X} 1$ variable against Y, the formula (n-2) $40-2=38$ at $\alpha=0.05$, then with df 38 , for two-tailed t test $0.95=1.6860$. Thus, it can be seen that $t_{\text {count }}=2.978562>t_{\text {table }} 1.6860$. Then, the researcher found out that work motivation is related to job satisfaction by using variable $\mathrm{X} 2$ to $\mathrm{Y}$, with the use of the formula (n-2) $40-2=38$ at $\alpha=0.05$, then with df 38 , for a two-tailed test $\mathrm{t} 0.95=1.6860$ it can be seen that $\mathrm{t}_{\text {count }}=2.497891>\mathrm{t}_{\text {table }} 1,6860$. Furthermore, the correlation between work environment and work motivation with job satisfaction is proven by the use of variables $\mathrm{X} 1$ and $\mathrm{X} 2$ against $\mathrm{Y}$ it is known that $\mathrm{r}_{\text {count }}=0.4514182$. Then the data is tested for the significance of the correlation compared to $\mathrm{r}_{\text {table }}$ at a

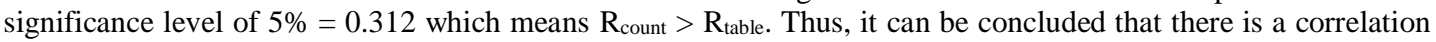
between work environment and work motivation with job satisfaction in Jambi Provincial Library and Archives Office.
\end{abstract}

Keyword: work environment, work motivation, job satisfaction

\section{INTRODUCTION}

One of the achievements of national development goals can be pursued by improving the quality of human resources. This should be realized because human resources have a strategic role as planners and implementers. Thus, the purpose of development will be easily realized, balanced by the good quality of the people who support it.

To achieve the goal of national development, the government has determined the steps to develop the quality of human resources as one of the directions and priorities of national development through improving the quality of education. This is in line with the mandate of the constitution of national education system which aims to develop the potential of students and to instill the core characters, including religious, noble, fit and healthy, knowledgeable, creative, independent, democratic and responsible.

Given the status of the framework of the human resource preparation, the need for improvements in library and archives is a must, for the newcomers to be able to solve any upcoming life issues. One of the general characteristics is the crowdedness of the newcomers. In such a condition, only those with a high quality of human resource can endure the competition. Regarding this situation, the attention to the aspect of long-term development is the improvements of human resource, due to the human act either as a subject and as an object of a decisive development.

The success of the implementation of educational activities in schools, among others, supported by personnel librarians and archives which is the determinant factor. Librarians are the spearhead in translating the school's mission of implementing learning services as the main activity in formal, informal and non-formal education. Thus, visitors have the ability to adopt innovative learning tasks.
The library employees need to have a good grip of the visitors because of the students whose attitudes and behavior are usually different. The development of science and technology has given impacts and cultural values of the learning community in Jambi city. It greatly affects the picture of the interaction between teachers and students in the good quality teaching and learning process, then the results of education are expected to improve its quality itself.

Therefore, any library visit appointment is conducted systematically from the perspectives of students, teachers and other supporting units. Basically, the employee's professional abilities are expertise, skills, and skills in serving visitors such as teachers/students and others who are required to read a lot.

One of the important things when talking about libraries is the sense of job satisfaction of librarians. Job satisfaction is a positive feeling about work that results from a characteristics evaluation (Robbins, 2015). Job satisfaction is a subjective emotional state for employees to evaluate themselves (Handoko, 2002). Job satisfaction is the general attitude of a person in dealing with their work, someone who has high job satisfaction has a positive attitude towards the job, while someone who does not get satisfaction in his/her work has a negative attitude towards the work he/she does (Sofyandi \& Garniwa, 2007). Based on those statements, the researcher can point out that is meant by job satisfaction is positive or negative feelings arising from the attitude of an employee's responsibility towards the work he/she does.

Work environment is all of the work facilities and infrastructure around employees which can affect the implementation of the work itself (Gonzali, 2003). Work environment is the overall tool that is faced by the surrounding environment where a person works, his/her work model, and his/her work arrangements both as individuals and groups (Sedermayanti, 2004). Work 
environment is every aspect that exists in the worker's environment that can affect him/her in carrying out tasks such as temperature, humidity, ventilation, lighting and noise, cleanliness of the workplace, and the adequacy of work equipment (Isyandi, 2004). Based on these opinions, the researcher points out that what is meant by the work environment is all work facilities and infrastructure contained in the worker's environment that can affect him/her in carrying out his/her duties and obligations as a worker.

Furthermore, work motivation is an intrinsic and extrinsic impulse that spurred a person to carry out an activity to achieve the goals (Muspawi, 2016). Work motivation can also be defined as a growing impulse in an individual, both from within and outside himself/herself to do a job with high enthusiasm using all the abilities and skills he/she has that aim to get the work and satisfaction as what he/she expected.

There is some research on job satisfaction has been done. For instance, a research conducted by Kartika \& Kaihatu (2010) showed that variables of work motivation significantly influence the employee job satisfaction at the Pakuwon Food Festival. Brahmasari \& Suprayetno (2008) explained that work motivation has a positive and significant effect on employee job satisfaction, it is also said that work motivation is really necessary for the employee to achieve high job satisfaction.

Meanwhile, Plangiten (2013) in his research said that the work environment variable $t$ value is equal to 7,795 which compared with $t$ table of 1,668 , this means that $t_{\text {count }}$ $>t_{\text {table. }}$. It means that the work environment has an effect on employee job satisfaction at PT. Pos Indonesia (Persero) Manado. Parimita, Handaru, \& Prayuda (2013) said that the work environment had a significant effect on job satisfaction with a significance value of 0.038 .

The effort made by Jambi Provincial Library and Archives Office to improve employees' performance did not run smoothly as planned, this was caused by several factors such as: low perceived work motivation, lack of awareness, lack of income, low job satisfaction, low leadership motivation, and consistently changing rules. A less supportive and less conducive work environment such as the presence of some improper buildings makes it less enjoyable in carrying out tasks. Another factor is lack of facilities, infrastructure, work equipment, teamwork and so forth. These factors will have a direct impact on an employee's work. Considering all the mentioned factors, the researcher is interested in studying further about the job satisfaction of employees of the Jambi Provincial Library and Archives Office, which is related to the work environment and motivation.

\section{METHODS}

In this research design, the author describes systematically about the problem, facts, and the relationship between the phenomenon investigated. This type of research is descriptive correlational, which means all the data collected and expressed in the form of numbers. The problem in this research is an associative problem, namely research that connects two or more variables (Sugiyono, 2013). Therefore, the model used is descriptive correlational which describes and examines the positive relationship between work environment and work motivation together with employee job satisfaction. The place of this research is the Jambi Provincial Library and Archieves Office. While the research was conducted from November 26 to December 10, 2018.

Sugiyono (2010) stated that the research variable is basically every aspect whatever the form is used by the researchers to be studied so as to get the information, and making a conclusion. Variables are various phenomena, which are the object of research (Arikunto, 2010). In this research, the independent variables are X: (X1) work environment and (X2) work motivation; (2) dependent variable (bound variable). The dependent variable is an independent variable, the dependent variable is the variable that is affected or becomes a result, because of the independent variable, the dependent variable is usually symbolized Y. The dependent variable in this research is employee job satisfaction.

The target population in this research is Jambi Provincial Library and Achieves Office. The reachable population is $100 \%$ of people who qualify. While the sample was taken as many as 40 people from the number of samples taken 100 people, the sample was selected by proportional random sampling technique.

The steps to take a sample were: (1) establish a sampling frame based on population, then count the number of employees who are included in the sampling frame; (2) give numbers from 001 to 100 , to all the employees; (3) draw to get a sample of 40 people from 100 people, taken randomly and balanced so they are represented; and (4) write the name of the sample member chosen to know the location of his/her work (teaching) for research purposes.

Data collected in this research are job satisfaction, work environment, and work motivation, all three variables of this research were captured through a questionnaire. Data netted using instruments in the form of a Likert scale of statements with four-scale answers. The instruments used for the three variables were developed through indicators of each variable. The instrument was tested before being used in research. Testing the instrument to see the level of validity and reliability. Invalid instrument items are discarded and not used as research tools.

The measurement of this research was carried out in a real situation, by the assessment of the respondents what they experienced, not what they wanted. The research instruments used were arranged in the form of statements. Instrument variables using a scale of four and with categories: (1) always; (2) often; (3) sometimes; and (4) never. From each variable for a positive statement item, if $\mathrm{a}$ is given a score of $4, \mathrm{~b}$ is given a score of $3, \mathrm{c}$ is given a score of $2, \mathrm{~d}$ is given a score of 1 , while respondents who answer negative statements, if answer a is given a score of 1 , if $\mathrm{b}$ is given score 2 , if $\mathrm{c}$ are given a score of 3 , if $\mathrm{d}$ is given a score of 4 .

The instrument reliability coefficient in seeing the consistency of answers given by library employees, was analyzed using "Alpha Cronbach". This method was chosen and considered by the instrument because the instrument was arranged to reveal the experience and assessment of employees, so that all items are considered to measure the same concept. The reliability coefficient of the work environment variable with $\mathrm{n}$ as much as 30 , the magnitude of the alpha coefficient of 0.95 . Instrument 
reliability coefficient calculation is done after validity testing by removing invalid instrument items.

\section{Data Description}

\section{RESULT}

According to the Table 1, it can be explained that for the data of work environment with 40 samples and a total score of 3829 with an average value of 95.73 , and standard deviation of 7.82, the highest value obtained was 20106 and the lowest was 82. For work motivation data with 40 samples then obtained a total value of 4660 , with an average value of 116.5 and the standard deviation was 8.64, the highest value obtained was 131 and the lowest was 100 . And job satisfaction data from 40 samples then obtained a total value of 4772 , with an average value of 119.3 , and the standard deviation of 18.21 , the highest value obtained was 155 and the lowest was 90 .

Table 1 Research Data Description

\begin{tabular}{|l|c|c|c|c|c|c|}
\hline \multicolumn{1}{|c|}{ Data } & N & $\sum$ & Mean & Sd & Max & Min \\
\hline Work environment & 40 & 3829 & 95.73 & 7.82 & 106 & 82 \\
\hline Work motivation & 40 & 4660 & 116.5 & 8.64 & 131 & 100 \\
\hline Job satisfaction & 40 & 4772 & 119.3 & 18.21 & 155 & 90 \\
\hline
\end{tabular}

\section{Data Analysis}

Before hypothesis test is conducted in order to see the contribution of variable, Normality test of the two data should be done first, then the data of normality test can be described as follows (Table 2).

Table 2 Normality Test

\begin{tabular}{|l|c|c|c|l|}
\hline \multicolumn{1}{|c|}{ Data } & $\mathbf{N}$ & $\mathbf{L o}$ & $\mathbf{L}_{\text {table }}$ & Description \\
\hline Work environment & 40 & 0.1338 & 0.1400 & Normal \\
\hline Work motivation & 40 & 0.1304 & 0.1400 & Normal \\
\hline Job satisfaction & 40 & 0.1398 & 0.1400 & Normal \\
\hline
\end{tabular}

Normality test shows that the data is normal because Lo $<\mathrm{L}_{\text {table, }}$ which are work environment data Lo (0.1338) $<\mathrm{L}_{\text {table }}(0.1400)$, work motivation data $(0.1304)<\mathrm{L}$ table $(0.1400)$, then data of job satisfaction Lo $(0.1398)<\mathrm{L}_{\text {table }}$ $(0.1400)$. Because the data has fulfilled, it can be continued to hypothesis test. In this research, hypothesis test is used to know the relation between variable $\mathrm{x}$ and variable $\mathrm{Y}$. As follows (Table 3).

Table $3 \mathrm{X1}$ and Y Correlation Test

\begin{tabular}{|c|c|c|c|c|c|}
\hline $\mathbf{N}$ & $\mathbf{X 1}$ & $\mathbf{Y}$ & $\mathbf{X 1}^{\mathbf{2}}$ & $\mathbf{Y}^{\mathbf{2}}$ & $\mathbf{X Y}$ \\
\hline 40 & 3829 & 4772 & 368913 & 582238 & 459165 \\
\hline
\end{tabular}

$r \mathrm{X}_{1} \mathrm{Y}=\frac{\mathrm{n} \cdot \sum \mathrm{X}_{1} \mathrm{Y}-\left(\sum \mathrm{X}_{1}\right)\left(\sum \mathrm{Y}\right)}{\sqrt{\left\{\left(\mathrm{n} \sum \mathrm{X}_{1}^{2}-\left(\sum \mathrm{X}_{1}\right)^{2}\right)\left(\mathrm{n} \sum \mathrm{Y}^{2}-\left(\sum \mathrm{Y}\right)^{2}\right)\right\}}}$

$=\frac{40.459165-(3829 \times 4772)}{\left.\sqrt{\left\{\left(40 \times 368913-3829^{2}\right)\left(40 \times \sum 582238-(4772)^{2}\right)\right.}\right\}}$

$=\frac{94612}{\sqrt{4.931 \mathrm{E}+10}}$

94612

$\overline{222059.25}$

$=0.4260665$

$\mathrm{T}_{\text {count }}=\frac{r \sqrt{n}-2}{\sqrt{1}-r 2}$ $=\frac{0.4260665 \sqrt{40}-2}{\sqrt{1-0.4260665}^{2}}$

$\mathrm{T}_{\text {count }}=2.978562$

By using the formula (n-2) 40-2 $=38$ at $\alpha=0.05$, then with df 38 , for a two tailed test t $0.95=1.6860$ it is easy to see that $t_{\text {count }}=2.978562>t_{\text {table }} 1,6860$. It turns out that there is a relationship between work environment and job satisfaction (Table 4).

\section{Table $4 \mathrm{X} 2$ and $\mathrm{Y}$ Correlation Test}

\begin{tabular}{|c|c|c|c|c|c|}
\hline $\mathbf{N}$ & $\mathbf{X 2}$ & $\mathbf{Y}$ & $\mathbf{X 2}^{\mathbf{2}}$ & $\mathbf{Y}^{\mathbf{2}}$ & $\mathbf{X 2 Y}$ \\
\hline $\mathbf{4 0}$ & 4660 & 4772 & 545800 & 582238 & 558192 \\
\hline
\end{tabular}

$r X_{1} Y=\frac{n \cdot \sum X_{1} Y-\left(\sum X_{1}\right)\left(\sum Y\right)}{\sqrt{\left\{\left(n \sum X_{1}^{2}-\left(\sum X_{1}\right)^{2}\right)\left(n \sum Y^{2}-\left(\sum Y\right)^{2}\right)\right\}}}$

$=\frac{90160}{\sqrt{6.02 \mathrm{E}+10}}$

$=\frac{90160}{245440.8}$

$=0.367339$

$\mathrm{T}_{\text {count }}=\frac{r \sqrt{n}-2}{\sqrt{1}-r 2}$

$=\frac{0.367339 \sqrt{40}-2}{\sqrt{1-0.367339}^{2}}$

$\mathrm{T}_{\text {count }}=2.497891$

By using the formula (n-2) 40-2 $=38$ at $\alpha=0.05$, then with df 38 , for a two tailed test $t 0.95=1.6860$ it is easy to see that $t_{\text {count }}=2.497891>t_{\text {table }} 1,6860$ then there is a relationship between work motivation and job satisfaction (Table 5).

Table 5 X1 and X2 Correlation Test

\begin{tabular}{|c|c|c|c|c|c|}
\hline $\mathbf{N}$ & $\mathbf{X 1}$ & $\mathbf{X 2}$ & $\mathbf{X 1}^{\mathbf{2}}$ & $\mathbf{X 2}^{2}$ & $\mathbf{X 1 X 2}$ \\
\hline 40 & 3829 & 4660 & 368913 & 545800 & 447595 \\
\hline
\end{tabular}

$r X_{1} Y=\frac{n \cdot \sum X_{1} Y-\left(\sum X_{1}\right)\left(\sum Y\right)}{\sqrt{\left\{\left(n \sum X_{1}^{2}-\left(\sum X_{1}\right)^{2}\right)\left(n \sum Y^{2}-\left(\sum Y\right)^{2}\right)\right\}}}$

$r X_{1} Y$

$=\frac{40.558192-(4660 \times 4772)}{\sqrt{\left\{\left(40 \times 545800-4660^{2}\right)\left(40 \times \sum 582238-(4772)^{2}\right)\right\}}}$

$=\frac{60660}{\sqrt{1.11 \mathrm{E}+10}}$

$=\frac{60660}{105311.3}$

$=0.576006$

$\mathrm{T}_{\text {count }}=\frac{r \sqrt{N}-2}{\sqrt{1}-\mathrm{r} 2}$ 
$=\frac{0.367339 \sqrt{40}-2}{\sqrt{1-0.367339}^{2}}$

$\mathrm{T}_{\text {count }}=4.456549$

With the formula (n-2) $40-2=38$ at $\alpha=0.05$, then with df 38 , for a two tailed test $t 0.95=1.6860$ it is easy to see that $t_{\text {count }}=4.456549>t_{\text {table }} 1,6860$ then there is a relationship between the work environment with work motivation (Table 6).

Table 6

Associative Hypothesis Testing

\begin{tabular}{|l|c|c|l|c|}
\hline \multicolumn{1}{|c|}{$\begin{array}{c}\text { Correlated } \\
\text { Variable }\end{array}$} & $\mathbf{r}_{\text {count }}$ & $\mathbf{r}_{\text {table }}$ & Description & $\mathbf{r}^{\mathbf{2}}$ \\
\hline $\begin{array}{l}\text { Work } \\
\text { environment }\end{array}$ & 0.4260665 & 0.312 & $\begin{array}{l}\text { There is a } \\
\text { correlation }\end{array}$ & 0.181533 \\
\hline $\begin{array}{l}\text { Work } \\
\text { motivation }\end{array}$ & 0.367339 & 0.312 & $\begin{array}{l}\text { There is a } \\
\text { correlation }\end{array}$ & 0.134938 \\
\hline Job satisfaction & $\mathbf{0 . 5 7 6 0 0 6}$ & 0.312 & $\begin{array}{l}\text { There is a } \\
\text { correlation }\end{array}$ & 0.331783 \\
\hline
\end{tabular}

The overall hypothesis testing used multiple correlation (ryx $1 \times 2)$ with the formula:

$\mathrm{Ry} \cdot \mathrm{x}_{1} \mathrm{X}_{2}=\sqrt{\frac{r_{y x 1}^{2}+r_{y x 2}^{2}-2 \cdot r_{y x 1} \cdot r_{y x 2} \cdot r_{x 1 x 2}}{1-r_{x 1 x 2}^{2}}}$

$=\sqrt{\frac{0.181533+0.134938-0.180303}{1-0.331783}}$

$=\sqrt{\frac{0.1361681}{0.6682166}}$

$=\sqrt{0.2037784}$

$=0.4514182$

Based on the calculation of data analysis between work environment and work motivation on job satisfaction, it is known that $r_{\text {count }}=0.4514182$. Then the data was tested for significance of the correlation compared to $r_{\text {table }}$ at a significance level of $5 \%=0.312$ which means $\mathrm{R}_{\text {count }}>$ $\mathrm{R}_{\text {table. }}$. Thus, it can be concluded that there is a relationship between work environment and work motivation on job satisfaction in Jambi Provincial Library and Archives Office.

\section{DISCUSSION}

Human needs are not always about the tangible, but also the intangible matters which affect their lives. Satisfaction is abstract, it cannot be seen but it can be found by looking at how far an individual's expectation towards his work has been reached. Job satisfaction is different in each individual, because it depends on their perspectives toward the job itself. One of the efforts for the company to keep their employees is paying attention to the job satisfaction.

Job satisfaction will not be fulfilled without work motivation and work environment. Work environment is matter around the employee that can give impact for them in order to do all of their obligations (Handoko, 2002). The major reason that makes accident happen while working is the uncomfortable environment, which lacks of tools and safety, broken equipment, narrow and dirty storage room, improper light and ventilation, bad air circulation, noises that will break hearing (Dessler, 2004). Work environment are all of the equipment needed, the exact location taken place, the method, the settings, whether in individuals and in groups.

According to Makeley (As'ad, 1999), a person has a desire to work because he or she expects that work will bring a better circumstance for him. Gilmer (As'ad, 1999) stated that working is about physics and mental process of human in order to reach their goals. By those several arguments, it can be concluded that working is a human activity physically and mentally which aims is to get satisfied. But it does not mean that all of activities can be defined as working. It depends on the motivation that is used as the basis of the activity.

Work motivation can be defined as an impetus which grows in individual's perspective, thus he or she can do his work enthusiastically using all of his ability and aptitude to get the results as well as reaching the satisfaction he or she wants. Employees/teachers need work motivation within them to give the good quality and quantity of their works, which will affect their work motivation so that they will be able to improve their skills. Since humans are social beings, they need love, recognizance, and the feeling of wanting those needs. Hence, for the sake of fulfilling all of their needs, they work and do the maximum efforts.

From the result, it can be explained that work environment data with 40 samples then obtained the total value 3829 with mean 95.73, and standard deviation 7,82, the highest point is 20106 and the lowest is 82 . For work motivation data with 40 samples then obtained the total value 4660 with mean 116,5 and standard deviation 8,64, the highest point was 131 and the lowest point was 100 . Work satisfaction data with 40 samples then obtained the total value 4772 , with mean 119,3 and standard deviation 18.21, the highest point was 155 and the lowest was 90 .

According to normality test Lo $<\mathrm{L}_{\text {table, those three }}$ variables data have normal data distribution because for work environment data Lo $(0.1338)<\mathrm{L}_{\text {table }}(0,1400)$, work motivation data $(0.1304)<\mathrm{L}_{\text {table }}(0,1400)$, and job satisfaction data Lo $(0.1398)<\mathrm{L}_{\text {table }}(0,1400)$. According to data processing calculation, the effect of $\mathrm{X} 1$ on $\mathrm{Y}$ using formula (n-2) $40-2=38$ with $\alpha=0,05$, with df 38 , for two tailed test $\mathrm{t} 0,95=1,6860$ so $\mathrm{t}_{\text {count }}=2.978562>\mathrm{t}_{\text {table }} 1,6860$ so there is a relation between work environtment and job satisfication. It matches with Plangiten research result (2013) stated that work environment the t count variable is 7,795 , which if it is compared to $t$ table 1,668 it means $t_{\text {count }}$ $>t_{\text {table, }}$, it is proven that work environment affects the job satisfaction of PT. Pos Indonesia (Persero) Manado.

This research also matches with Pangestu et al (2017), Kesuma (2007), Wirawan \& Sudharma (2015), and Murtafia \& Suryalena (2015) research result proves that work environment affects job satisfaction. Although there is another research which proves that work environment does not have a relation or significant effect towards job satisfaction, Dhermawan, Sudibya, and Utama (2012) stated that work environment does not give any significant effect towards job satisfaction. As seen from coefficient 
standardized regression weight in amount $0,063, C . R$ in amount 0,905 , and probability 0,365 . Riansari, Sudiro, and Rofiaty (2012) said that direct impact testing between work environment and job satisfaction coefficient path in amount 0,113 is obtained, with Critical Ratio (CR) in amount 1.28 and p-value in amount 0.20. Because CR > 1.96 and $p$-value $<0.05$, it can be concluded that there is no significant direct effect between work environment and job satisfaction.

Furthermore, this research result proves that the relation of X2 and Y using formula $(n-2)=40-2=38$ with $\alpha=0,05$, with $\mathrm{df} 38$, for two tailed test t $0,95=1,6860$ so $t_{\text {count }}=2.978562>t_{\text {table }} 1,6860$ so there is a relation between work motivation and job satisfaction. It matches with Kartika \& Kaihatu (2010) research result stated that work motivation variable affects job satisfaction significantly in Pakuwon Food Festival. Brahmasari \& Suprayetno (2008) explained that work motivation gives a positive effect significantly towards job satisfaction, they also stated that work motivation is indispensable for employees to get the maximum job satisfaction. This matches with Herman \& Rahmawati (2012) which stated that there is a relation between work motivation and job satisfaction as well.

Furthermore, based on analysis result data between work environment and work motivation towards job satisfaction $r_{\text {count }}=0.4514182$. After that, the data tested significance of correlation compared with $r_{\text {table }}$ at significance $5 \%=0,312$ which means $R_{\text {count }}>R_{\text {table. Thus, }}$ it can be concluded that there is a relation between work environment and work motivation towards job satisfaction in Jambi Provincial Library and Archives Office. This result matches with Wuwungan, Taroreh, Uhing (2017) research result, stated that simultaneously there is a relation between work environment and work motivation towards job satisfaction.

\section{CONCLUSION}

According to the result, it can be concluded that: (1) there is a relation between work environment and job satisfaction in Jambi Provincial Library and Archives Office; (2) there is a relation between work motivation and job satisfaction in Jambi Provincial Library and Archives Office; and (3) there is a relation between work environment and work motivation towards job satisfaction in Jambi Provincial Library and Archives Office.

\section{REFERENCES}

[1] Brahmasari, I. A., and Suprayetno, A. 2008. Pengaruh Motivasi Kerja, Kepemimpinan dan Budaya Organisasi terhadap Kepuasan Kerja Karyawan serta Dampaknya pada Kinerja Perusahaan (Studi Kasus pada PT Pei Hai International Wiratama Indonesia). Jurnal Manajemen dan Kewirausahaan, 10(2), 124-135.

[2] Dessler, G. 2004. Manajemen Sumber Daya Manusia. Jakarta: Indeks Kelompok Gramedia.

[3] Dhermawan, A. A. N. B., Sudibya, I. G. A., and Utama, I. W. M. 2012. Pengaruh Motivasi, Lingkungan Kerja,
Kompetensi, dan Kompensasi terhadap Kepuasan Kerja dan Kinerja Pegawai di Lingkungan Kantor Dinas Pekerjaan Umum Provinsi Bali. Jurnal Manajemen, Strategi Bisnis, dan Kewirausahaan, 6(2), 12-22.

[4] Gonzali, C. 2003. Teori Akuntansi. Semarang UNDIP

[5] Handoko, T. 2002. Manajemen Personalia Sumberdaya Manusia. Yogyakarta BPFE.

[6] Herman, D., \& Rahmawati, M. 2012. Pengaruh Motivasi terhadap Kepuasan Kerja Pegawai pada Kantor Dinas Peternakan dan Perikanan Kabupaten Sidenreng Rappang. JIA,1(1),17-39.

[7] Isyandi, B. 2004. Manajemen Sumberdaya Manusia dalam Perspektif Global. Pekanbaru: Unri Press.

[8] Kartika, E. W., and Kaihatu, T. S. 2010. Analisis Pengaruh Motivasi Kerja terhadap Kepuasan Kerja (Studi Kasus pada Karyawan Restoran di Pakuwon Food Festival Surabaya). Jurnal Manajemen dan Kewirausahaan, 12(1), 100-112.

[9] Kesuma, A. 2007. Lingkungan Kerja, Motivasi, dan Budaya Organisasi terhadap Kepuasan serta Dampaknya terhadap Kinerja Pegawai. Jurnal Bisnis dan Manajemen, 1(4), 310-322.

[10] Murtafia, I., \& Suryalena. 2015. Hubungan Lingkungan Kerja dengan Kepuasan Kerja Karyawan (Kasus Bagian Pengolahan PT Surya Bratasena Plantation Kecamatan Pangkalan Kuras Kabupaten Pelalawan). JOM FISIP, 2(2), 1-15.

[11] Muspawi, M. 2016. Pengaruh Kepemimpinan Transpormasional, Budaya Organisasi, dan Motivasi Kerja terhadap Keinovatifan Ketua STAI di Provinsi Jambi. Jambi: IAIN Sultan Thaha Saifuddin Jambi.

[12] Pangestu, Z. S. D., Mukzam, M. D., and Ruhana, I. 2012. Pengaruh Lingkungan Kerja terhadap Kepuasan Kerja (Studi pada Karyawan Perum Perhutani Ngawi). Jurnal Administrasi Bisnis (JAB), 43(1), 157-162.

[13] Parimita, W., Prayuda, W. H., and Handaru, A. W. 2013. Pengaruh Lingkungan Kerja dan Budaya Organisasi terhadap Kepuasan Kerja Karyawan pada Bank BTN (Persero) Cabang Bekasi. Jurnal Riset Manajemen Sains Indonesia (JRMSI), 4(2), 13-22.

[14] Plangiten, P. 2013. Gaya Kepemimpinan dan Lingkungan Kerja Pengaruhnya terhadap Kepuasan Kerja Karyawan pada PT Pos Indonesia (Persero) Manado. Jurnal EMBA, 1(4), 2155-2166.

[15] Robbins, S. P. 2015. Perilaku Organisasi. Jakarta: Prenhallindo Prenadan Median Group.

[16] Sedermayanti. 2004. Sumberdaya Manusia dan Produktivitas Kerja. Bandung: Mandar Maju.

[17] Sofyandi \& Garniwa, 2007. Prilaku Organisasional. Yogyakarta: Graha Ilmu.

[18] Sugiyono. 2013. MetodenPenelitian Bisnis. Bandung: Alfabeta.

[19] Sugiyono. 2009. Metode Penelitian Pendidikan. Bandung: Alfabeta

[20] Wirawan, I. D. G. K., \& Sudharma, I. N. 2015. Pengaruh Komunikasi, Motivasi dan Lingkungan, Kerja Fisik terhadap Kepuasan Kerja Pegawai Sekretariat Daerah Kota Denpasar. E- Jurnal Manajemen Unud, 4(10), 3037 3062.

[21] Wuwungan, R. Y., Taroreh, R. N., \& Uhing, Y. 2017. Pengaruh Lingkungan Kerja dan Motivasi Kerja terhadap Kepuasan Kerja Karyawan Cinemaxx Lippo Plaza Manado. Jurnal EMBA, 5(2), 298-307. 